\title{
Ethics, Interpretive Social Science and War
}

\author{
Mervyn Frost \\ King's College London, Department of War Studies, London, UK \\ mervyn.frost@kcl.ac.uk
}

\begin{abstract}
This chapter explores radical interpretivism as an approach to understanding contemporary war and the implications that flow from its application to questions about what ought to be done in contemporary asymmetrical wars. It argues that the currently dominant version of the relationship between just war theory and the world to which it is to be applied is misguided. It is widely held that policymakers facing ethical decisions about war and peace, have first to ascertain the empirical state of affairs in which they find themselves, and then, in a second step, consider what it would be ethical to do, given the circumstances. On this view, questions about the justice of going to war arise only after the completion of an empirical analysis about how things stand in the world. Radical interpretivism denies the possibility of determining a given "state of affairs" in social relations in purely empirical terms that do not involve engaging with ethical considerations from the outset. A central strand of the argument is that in the analyses of the circumstances that precede wars, what must be understood are the histories of actions and reactions of the parties involved. These, as is the case with all actions, can only be understood within the social practices in which the actors are participating. Such understandings involve an ethical engagement at every point. This interpretive approach is particularly important for a proper understanding of asymmetrical wars.
\end{abstract}

\section{Keywords}

radical interpretivism - just war theory - ius in bello - asymmetric war - war empiricism 


\section{Introduction}

The scholarly conversation which gave rise to this special edition of the journal revolved around the following question: How is it possible to dovetail empirical social scientific accounts of war with the normative work of just war theorists? A second, and more general, phrasing of the question might be: What is the relationship between empirical social science and ethical theory? In what follows I argue that these questions, as posed, are misguided. The argument offered here is that there are not two distinct forms of social inquiry: one empirical and the other normative/ethical. Instead, it is fundamentally important for all scholars focused on the study of war and conflict (and all other social phenomena) whether focused on the micro, meso or macro levels, to understand that a proper comprehension of any war or conflict requires an engagement with ethical questions at every point. In short, the ethical dimensions of social scientific inquiry into war (and any other social activity) do not form a domain that is in some sense fundamentally separate from a realm of pure empirical inquiry. The chapter outlines how practice theory as developed by Silviya Lechner and me in Practice Theory and International Relations can elucidate the entanglement of ethical considerations in depictions of conflict and war. ${ }^{1}$ The chapter starts by setting out a well-known approach to just war theorizing which, on the face of the matter, suggests a clear distinction between the empirical study of war and the consideration of its ethical dimensions. This traditional approach obscures the intense salience of ethics for a proper understanding of all wars. Towards the end of the chapter a consideration of the so called "New Wars" is used as a way of bringing the ethical dimensions of all analyses of war and conflict to light. The chapter deploys a radical interpretivist approach to understanding what has come to be known as asymmetrical war.

A caveat at the outset is in order. The goal of this chapter is not to criticise any specific version of just war theory. It does not set out to make a contribution to the vigorous and ongoing debate between, for example, orthodox and revisionist interpretations of just war theory. ${ }^{2}$ Instead, it is about the important task of interpreting war in a world of states and about the ways in

Lechner and Frost, Practice Theory (2018).

2 The most influential work in the orthodox tradition is Walzer's Just and Unjust Wars, (1980) and key figures in the revisionist school are McMahan, Killing in War, (2011), Fabre, Cosmopolitan War, (2012), and Rodin, War and Self-Defence, (2002). 
which ethical considerations, including those do to with the just war tradition, are necessarily involved in the production of such interpretations. A proper understanding of this dimension is of fundamental importance for all those who become involved in wars, be they politicians, men and women serving in conventional military roles, men and women fighting in unconventional fighting units ("terrorists" "freedom fighters" "guerrillas"), civilians, or academics studying war.

\section{Interpreting the History of Interaction that Lead to War}

The decision by the government of a state to go to war is always a decision based on an interpretation of a given state of affairs. This involves a reading of the interactions between it and other states that lead up to the point of decision. Metaphorically, we might say that it is an interpretation of the "state of play" in the interstate practice. This overall interpretation is based on an interpretation of a complex history of interactions between states. Knowledge of this is not gained by some straightforward perception of the empirical facts of the matter, of how things stand "out there" as it were. For the actions involved in this history, like all social actions, can only be understood in the context of the social practices in which they are constituted as actions of a certain kind. Such understanding must be (can only be) understood from within the social practices in which they are located. Just as what is to count at "making a move" in a board game (for example, chequers or chess) can only be understood from the point of view of a player in the game, so, too, the actions of states (diplomatic demarches, signing treatises, declaring war, and so on) can only be understood in terms of the wider rules of the global practice of sovereign states as understood by a state participating in that practice. The point here is not one about the subjective perspective of participants, accessible through interviews and documents. Instead, the internal point of view refers to the rules of the practice (rules of the game) which must be understood by any would be participant as a condition of participation. The internal point of view must not be understood as indicating how an individual placed in certain circumstances might weigh up various possibilities to determine how best to maximize his advantage all things considered. The rules to be understood from the internal point of view, are those which set out the conditions of possibility for participation of an actor in a specific practice. These must be understood prior to the making of any utilitarian calculation about the advisability of making this move or that one. These constitutive rules specify that "If an actor wishes to play chess these are the rules to be followed"; or, "If an actor wishes to buy and 
sell in the market, these are the rules for participation"; or "If a group of actors wishes to participate as a state in the practice of states, the rules to be followed are." and so on.

Social practices have a range of different kinds of rules that must be understood and followed by participants in the practice. There are rules which specify what is required to qualify as a participant, there are rules which spell out the possible actions available to participants, there are procedures for settling disputes between participants and for punishing those who transgress the rules. Crucial for the present argument is the requirement in all social practices that participants understand and commit to upholding the values embedded in the practice in question. As a condition of participation participants need to understand the ethics of the practice. For example, students seeking to participate in the practice of university life must learn that the underlying values of this practice are those relating to truth seeking through the exchange and the testing of ideas by experiment or by exposing them to public scrutiny, and so on. Players entering sports practices are required to learn about the value of fair play built into the games they play. States in the practice of states learn about the value attached to the recognition of and respect for the freedom involved in the notion of sovereignty. Rights holders in the global rights practice, as a condition for their participation, learn about the value attached in this practice to individual freedoms. It is important to stress that the ethical values embedded in social practices are not ones that participants are free to choose or reject. These are not their personal choices, but what is required as a condition of participation.

At the global level the two major practices within which most people, everywhere, participate are, first, the practice of sovereign states, and, second, the global rights practice (sometimes referred to as global civil society). These practices have features that distinguish them from games and many other practices. First, they are global. Most people in most places are participants in them. In a sense, then, they are universal, but of course, not timeless. Second, they are macro practices, that is, they are practices of practices. Whatever other practices individuals might participate in are themselves subsumed in these overarching practices. Third, there is a coercive element to these practices. Individual participants in them did not join them voluntarily as they might join a club or association. They simply found themselves constituted as participants in them. They are also coercive in that the participants in them do not have any formal method of resigning or leaving these practices. There is no way in which individuals can remove themselves and stand outside these practices. Fourth, these two global practices, unlike games, are not static, but change and are changed by the actions of the participants in them. Finally, built into both 
practices are ethical constraints based on what one might broadly label "just war" considerations which determine the circumstances under which participants might justly resort to lethal force against others.

Let us examine in more detail this feature within the society of sovereign states. In the practice of sovereign states, participant states know how to recognize those actions by other states that might properly be interpreted as acts of war. In the practice, as it is currently constituted, the best known such action is an act of aggression by one sovereign state against the sovereignty of another. The crucial point here is to note the ethical component in identifying $\mathrm{X}$ as an act of aggression that warrants the target state going to war in response to $\mathrm{X}$. The description of $\mathrm{X}$ as "an act of aggression" is not a simple account of some empirical brute facts about movements of military personnel and the machinery of war-making. Crucial to the description of $\mathrm{X}$ as "an act of aggression", is that it is understood as a wrongful action that undermines the core value of sovereign freedom constituted in the society of sovereign states. That this interpretation is easily and quickly made by participants in the practice should not lead us to claim that such an act is simply perceived in an empirical/objective way. The deed in question "an act of aggression" cannot be identified as such by straightforward observation but, must be understood. Such understanding involves comprehending it as wrong when judged by the ethics internal to the practice.

Embedded in the global rights practice is an analogous "just war" component according to which, at the limit, rights holders in this practice are entitled to resort to force in extreme circumstances usually described as "in self-defence". When a rights holder in this practice faces a wrongful threat to his/her life and when all other avenues to defend it have been exhausted, it is considered justified to use force to protect oneself. The key point here, once again, is that identifying an act as one that would justifiably trigger a justified violent response, involves an ethical interpretation of that act as wrongful as understand from within the practice of rights.

\section{The Limits of Orthodox Just War Theory for Understanding Contemporary Conflict}

After a state actor's history of action has been judged to constitute an act of wrongful aggression against one or more other states, then the targets of such action must decide whether it would be just to go to war against the aggressor. In the contemporary practice of states, it is on such occasions that the just war tradition comes into play. The key features of this are well understood 
by participant states and they are embodied in international law. One statement and elaboration of these is provided by my late colleague at King's, David Fisher who listed the criteria that must be applied by a legitimate authority when considering going to war, as just cause; reasonable chance of success; proportionality; right intention; and last resort. ${ }^{3}$ As already indicated, the major just cause that may trigger a just war is unwarranted aggression by one state against another. ${ }^{4}$ Once war has commenced the belligerents are required to abide by the ius in bello - that is in fighting the war their actions must be constrained by the following principles (amongst others): the war effort must be directed towards combatants only (non-combatants are to be protected); the force used must be proportional to the end sought; the use of certain weapons (chemical and biological) is forbidden; prisoners of war are to be treated in a prescribed way; and so on. ${ }^{5}$

The assumed social context within which such just war thinking is to be applied is clear. It consists of a society of sovereign states and the just war tradition is directed towards constraining and limiting the conduct of war between the states in it. Note that the just war tradition just described, conspicuously does not consider questions of justice in general. It starts with the way the world is now and does not ask questions about whether the contemporary arrangements of our world order are just or not. War on this view is directed towards maintaining the status quo ante as it existed prior to the act of aggression that precipitated it. This version of the just war tradition does not ask questions about how this practice came into being and whether the path to its present form involved grave injustices to one or more of the participants in the process. It does not ask whether under certain circumstances historical injustices might provide justifiable grounds for going to war.

The just war tradition as articulated in this way, may be seen as offering a useful summary of the core features of the ethical constraints on war that are currently built into the global practice of states. It is, one may say, a checklist which a state may use when contemplating going to war in order to determine whether doing so would be just or not. However, it is important to note that it leaves out of account questions such as the following: are nations that do not yet have sovereign states of their own, ever justified in resorting to force

3 Fisher, The Morality of War (2011), obiter.

4 To this just cause, Michael Walzer adds going to the aid of an ally who is being aggressed against and with whom one has a treaty commitment to provide such aid. Another addition is one which specifies that where a civil war is taking place in one state and a foreign power intervenes on one side, then intervention to oppose this would be justified. Walzer, Just and Unjust Wars: (1980), 96-97.

5 Ibid., 111. 
to achieve national self-determination? Are groups of individuals within sovereign states who find that their rights are being denied them by the states in which they live, ever entitled to resort to force to free themselves from the oppressive regimes within which they find themselves? Are nations entitled to use arms to secure their liberation? Are there ever circumstances in which religious groups, who consider that they are being oppressed by a secular order, have a right to use force to oppose such oppression? Is there ever a case to be made for the use of force against dominant economic powers (be they states or private corporations) whose activity results in extreme poverty for groups of people in specified geographical areas? Might there be circumstances in which a state that suffers severe water shortages caused by the acts of another state, may justly go to war against such an aggressor? The just war tradition as currently articulated by Michael Walzer, as it is embodied in international law and supported by the United Nations, does not provide answers to such questions. With some minor amendments it asserts that the use of military force is only ever justified in response to unwarranted military aggression. Yet it is important to note that the questions listed earlier in this paragraph are not incomprehensible to those reading this chapter. If this is true, then it indicates a richness of ethical content in the global practices within which we are participants. This is a richness that takes us beyond the checklist and conventional nostrums of orthodox just war theory. These questions challenge us when we seek to understand the global practices and to determine how we ought to act within them. They identify, one might say, the hard ethical conundrums we face in our contemporary global practices.

A significant attempt to articulate the ethical values informing our understanding of the ethical questions posed in the previous paragraph is to be found in the discussion, political processes and actions that lead the states of the General Assembly of the United Nations to propose and adopt the emerging principle of the Responsibility to Protect $\left(\mathrm{R}_{2} \mathrm{P}\right)$. This authorises a military response to gross human rights violations, ethnic cleansing, war crimes and genocide. This principle, though, is not (yet) embodied in international law.

Similarly, the work of the revisionist just war theorists such as Jeff McMahan, Cecile Fabre and David Rodin attempt to provide answers to these questions in a way that orthodox just war theory has failed to do. ${ }^{6}$ Their work highlights the importance of human rights for any actor contemplating the use of force in global politics. It fundamentally challenges the narrow focus on states' rights that has informed orthodox just war theory.

6 See the sources referred to in footnote 2 above. 
There may well be good pragmatic reasons why orthodox just war theorists (and why we as participants in world politics) have not satisfactorily answered the questions posed above. These are (amongst others): that doing so would involve a search for a comprehensive global theory of justice (what Michael Walzer calls a "thick" ethical theory). Such a theory would have to command widespread agreement from most people, in most places, if it were to have any chance of being implemented and the chances of achieving such agreement are extremely slim. Also, in seeking to construct such a comprehensive global theory of justice it would be important to reach ethical conclusions about world history, which is a long saga of conquest, subjugation and exploitation of the weak by the strong. It is obvious that any search for a globally applicable theory of world justice, would itself raise a host of disputes. Facing the certainty of such disputes, it is easy to why, for pragmatic reasons, many might be happy to continue with the rather minimalist version of the just war tradition that currently enjoys widespread acceptance in the society of sovereign states and the citizens in them. Another good reason for supporting this minimalist version is that its core features are already embodied in international law and supported by international organisations. The minimalist tradition embodied in international law acts as a living constraint on war in the modern world. Specifically, it acts as a constraint on the occurrence of wars between sovereign states.

In spite of such pragmatic reasons for accepting this strictly limited just war theory, we might well be sceptical of a theory that rules out even considering so many of the wider questions of justice for which people have regularly indicated their preparedness to fight (and die) in pursuit of a just outcome. The most prominent of these are those which refer to people's struggles for recognition of their human rights and their struggles for their right to self-determination.

A more pressing reason to doubt the utility of the narrowly construed just war theory is that it seems to offer so little to advance our understanding of most of the violent conflicts taking place in world politics today. The core problem here is that in the 21st-century most armed conflicts do not conform to the conventional model of war that focused on wars between states. Such wars had beginnings and ends. They were fought between armies confronting one another fighting on identifiable battlefields and success was measured in terms of territory gained and held. For the most part the military forces involved were clearly identifiable as such, that is, as soldiers, sailors and airmen (and women). There are few wars nowadays that fit this template. Instead what we now have are armed conflicts which are referred to by a variety of different names - "wars of national liberation", "new wars", "asymmetrical wars", 
"wars on global terror", and "humanitarian interventions in response to gross human rights abuses". These labels do not neatly classify different kinds of war in the contemporary world. In many cases several of these labels are pertinent to a given conflict. Some of the distinctive features found in this broad range of conflicts include: that they are not wars between sovereign states; that in them there is no clear distinction between combatants and non-combatants; that between the belligerents the question of legitimate authority is highly contested; that in many cases only one of the belligerents is a state; that there is an almost complete absence of set-piece battles; that the weapons used are often simple and primitive; that there is often no clarity about the final aims of the belligerents; that such conflicts often take place in weak or failed states; that although these conflicts take place on the territories of weak or failed states there is also regularly a large measure of involvement by powerful states who are engaged in what has come to be called "proxy wars" in the territory of such failed states; a key method in such wars involves the use of terrorist methods; a prominent component in many such wars involves ethnic cleansing and the use of rape as a method of war; that although these wars might be fought for political or religious reasons, there is often also a strong element of criminal activity closely associated with one or more of the actors involved. ${ }^{7}$ An extraordinary feature of many such wars is that although they start locally many of them quickly develop an international dimension in that fighters from the groups involved resort to acts of terror elsewhere in the world. This feature has the effect of scaling up the "battlefield" to include all places everywhere. The wars then become wars without any specific location. A central feature of these new modes of warfare is that the participants often make extensive use of modern communication technology, specifically, social media. Such technology has allowed small groups to organise themselves into fighting units in spite of their being located in disparate places world-wide. Distance from one another is no obstacle to their being able to form fighting units quickly, cheaply and easily.

In the face of the developments described, it is self-evident that the normal tick box list of criteria encapsulated in traditional just war theory is not useful for a state trying to determine whether an armed response to any of these new warlike actions by non-state actors would be justified or not. At the most basic level, indeed, it is not even clear whether it is appropriate to describe such conflicts as "wars" and therefore not clear whether (or not) it would be appropriate to consider the application of just war criteria to such conflicts. In these "new wars" it is not clear who or what would be the legitimate authority to wage

7 See Kaldor, New and Old Wars, (1998). 
the war, what would count as a reasonable chance of success, what counter measures would be proportional, what would count as a right intention, and what would count as having reached the stage when war is the last resort for resolving the conflict.

Before going on to consider in greater detail how to interpret such new wars, let us briefly focus again on the traditional just war theory as it has come down to us and the typical circumstances for its application. Doing this will bring into even sharper focus the starkly different contours of new wars. The focus of the traditional model in modern times has been large-scale military conflict between sovereign states (already on the go or about to take place). The circumstances to which it is applied are clearly apparent to all the actors involved and there is not much scope or call for nuanced interpretation. Consider the case of the Iraqi invasion of Kuwait on 2 August 199o. It involved a massive military incursion by Iraq into the territory of Kuwait. There was no ambiguity about what had happened. The international community fully understood what had been done. This was unambiguously wrongful aggression by one sovereign state against another. The vast majority of states participant in the global practice of sovereign states saw it as such. This action was not only ethically wrong in terms of the ethics embedded in the global practice of states, it was also clearly contrary to international law. This was overt aggression in that it involved a state's military apparatus embarking on an attack on another sovereign state without just cause. At that point it was clear that the only effective way to counter this wrongdoing would involve a military response. In such a case one can clearly see the point and purpose of the traditional just war principles embedded in the practice of sovereign states. It is narrowly focused on authorising the use of the military machine of one or more states. This is normally forbidden. The reason for the limits on the use of military instruments are self-evident. The destructive power of modern military apparatuses is great. Not surprisingly a core function of much international law, many international organisations, and states themselves, has been to curtail the deployment of such massive military force. This has been done to prevent a recurrence of the death and destruction that resulted from the deployment of such forces in World War I, World War II, the Korean War, the war between Iran and Iraq, and more recent wars in the Middle East. ${ }^{8}$ Not only are such wars destructive, but once embarked on the outcomes are unpredictable. The just war tradition has been developed in its modern form strictly to limit the occasions on which modern military forces might justifiable be deployed. Even

8 In the background is the ever-present possibility of conventional wars escalating to nuclear war. 
in those limited circumstances in which war is justified, the aim of such wars must be limited to restoring the status quo ante. The key point of this paragraph, though, is to stress that the circumstances to which this conventional just war theory is applicable are ones where the "state of play" (including its ethical dimensions) is obvious to all. In those cases where the principles come into play there is not much room, need or time for subtle interpretation. The principles authorise a response when an attack has occurred or is imminent. There is little call for nuanced evaluation, explanation, or description of "What is happening." The question to be answered is simple "Would the target state be ethically justified in unleashing its military might to counter a wrongful military attack against it?"

The circumstances that obtain in the "new wars" are quite different. It is often difficult to determine who is doing what, to whom, for what reasons, and with what goals in mind. In such cases the need for a sophisticated interpretation is paramount. Indeed, no plausible response is possible absent such an interpretation of "what's happening?" Or, to put it another way, the possibilities for misinterpretation are myriad and the consequences that flow from misinterpretations are likely to be dire. In these "new wars", the trigger which raises the question "Would a violent military response to this be justified?" is always the commission of a violent act contrary to domestic and international law in one or another state and contrary to widely accepted ethical principles. In seeking to find an appropriate response the simple set of tick box criteria of the just war tradition (legitimate authority, just cause, reasonable chance of success, proportionality, last resort) are not of much help. They offer little guidance because it is not clear who the enemy is, what military assets the enemy has, what the goals of the enemy are, what would count as a successful military operation against this shadowy enemy, what the core sources of the enemy's power are, and so on. It is also not clear what would count as successful conclusion to such a war. A conclusion involving a peace treaty would seem to be highly unlikely. The violent acts that precipitate international interest in these so-called "wars" are prominent, destructive and dramatic. Notwithstanding this fact, it is far from clear how to make sense of them. Nevertheless, it is imperative that we do so, for at the limit these "wars" might threaten an erosion of the very global practices within which they are taking place. Citizens and governments alike, cannot ignore them. A response is called for, but not any response will do. The right one depends on the veracity of the initial interpretation of the violent actions in question.

In what follows I shall set out, once again, how any successful attempt to make sense of such warlike actions would not involve a two-step process determine the facts then apply just war prescriptions - instead interpreting 
such actions necessarily involves investigations that have a strong ethical component from beginning to end. No neutral account of the interaction between the participants in the run-up to asymmetrical wars is possible. The "facts" are not accessible through simple observation. That is, there can be no "ethics free" account of the relationship between the great power side of this relationship, on the one hand, and the minor party, on the other. The history leading up to the state of affairs in which such violent acts take place can only properly be set out through the social scientific procedures of radical interpretivism or what Lechner and I call practice theory.

Let me once again list the defining features of this method. Its focus is always on actors and their actions in the context of the social practices in which they are constituted as actors and actions of a certain kind. Interpretation is significantly different from straightforward observation. The difference lies in the way that interpretation always requires that the investigator (the social scientist or layperson) have prior knowledge from the internal point of view, of the practice in which the actor is participating and in which the action takes place. What is central to the internal point of view is that it requires an understanding of the ethical dimensions of the practice(s) under investigation.

In what follows, as an example of this mode of inquiry in action, I shall present a simple narrative of the conflict currently going on in Syria. It is my understanding, from the internal point of view, of some actors and their actions in this ongoing war. Note that I can do this (come to this understanding and present it to you), despite the fact that I am not an expert on the region. I have no detailed knowledge of the languages spoken there, of the religious beliefs of those who live there, of the political parties and other formations operative in the Syrian political system, of the various factions that have been united in what has come to be known as the "Free Syrian Army" and I know next to nothing about the personalities of the various leaders of the diverse small groups engaged in this war. The goal in what follows is not to present a definitive version of what happened in Syria. I do not have the expertise to offer one. My goal is to portray the kind of argument that any plausible account of the conflict must exhibit. What I offer here, is, if you like, a meta-theoretical argument.

Keeping in mind the ignorance that I have just professed I ask the reader to consider the short interpretation (narrative) of the war in Syria that I present below. If it is at all plausible, then the next pressing question must be: What makes it possible for me to offer such a plausible interpretation? In presenting such a narrative, I'm doing no more than what every newspaper reader or electronic media reader does in interpreting such new wars. The short answer to the question posed is that we are able to do this because we, together with those violent actors whose deeds we are attempting to interpret, are participants in 
the social practices within which we and they are active. The key words in the previous sentence are "participants" and "practices". What this alert us to is that what is essential to begin a rudimentary interpretation of such acts is not detailed knowledge about the sorts of things I have just listed, but some understanding of the constitutive rules of the practices in which the actions of these actors are taking place. An important aspect of this is an understanding of the ethical considerations embedded in the constitutive rules of these practices.

Returning now to consider the conflict in Syria, I start by noting that before the war it was a stable state in which a government dominated by the Alawites (a subgroup of Shia Islam, who are a minority in Syria) ruled over the country which is populated by diverse ethnic and religious sects. The majority religious group was/is Sunni Islam. The government was not democratic or particularly committed to the protection of human rights. At the start of the conflict several different groups, prompted by the failure of the government to deal with an extended famine in the south of the country, inspired by the activities now known as the "Arab Spring," rose up against the government. There were several competing interpretations of what these groups were doing. Here I list some of them: First, President Assad's government interpreted the uprising as a sectarian upheaval by Sunnis against the legitimate secular and sovereign state which protected minorities and women. ${ }^{9}$ Second, many of the groups opposed this characterization of what they were doing and insisted that they were engaged in a legitimate civil war against a rights abusing regime. They presented themselves as opposing a dictatorship. So, which of the alternative interpretations is correct: the government of a sovereign state opposing a sectarian uprising that made use of terrorist methods, on the one hand, or, a legitimate uprising against a dictatorship, on the other? What kind of arguments might sway our interpretation in one direction rather than another? In order to make the case that it was fighting terrorists the regime had to be able to point to terrorist activity. It would not do for it to simply allege that such terrorist activity was taking place. There had to be some truth in its allegation..$^{10}$ This was not difficult for it to do. For ironically, the groups fighting the regime of President Assad and who had formed themselves into the Free Syrian Army (FSA), had their own good reasons for engaging in such terrorist activity. These arose because the FSA found itself in an asymmetric war. As is always the case

9 This was confirmed recently in a presentation at King's by Dr Bassma Kodmani spokesperson for the Syrian Opposition's negotiating team at the United Nations talks in Geneva. She was discussing the problems her organisation had with their attempts at strategic communication. 
in such wars in which a militarily strong state confronts a much weaker small, informal, fighting group. Such a group is not able to embark upon anything like a conventional war against the traditional state. Instead, its source of power depends on it being able to spring a set of ethical traps on its powerful opponent. ${ }^{11}$ Such ethical trapping required it to provoke the Syrian state into a series of actions which infringe the fundamental ethical norms of the global practices in which it is constituted as a state actor. In this case, the FSA had to commit acts which would provoke the government of President Assad (and his allies) into acts that offended fundamental international ethical norms. The standard method used by the FSA to achieve this effect was/is to hide its fighters among civilians. Doing this blurred the distinction between combatants and non-combatants which distinction rests on ethical considerations embedded in the global practice of states and embodied in international law. The outcome that followed, as night follows day, was that when the government used its military might to attack the fighters of the FSA it invariably resulted in the deaths of unarmed civilians. Once it had done this, it was clearly guilty of terrorism (simply defined as indiscriminate violence). It demonstrated itself to be engaged in terrorist acts that killed and maimed innocent bystanders. This claim is strengthened further by it adopting the following technique: the FSA forced civilians into installations such as hospitals and schools which are supposed to be off-limits to military attacks under a whole series of international conventions. ${ }^{12}$ Once again the fighters were hidden amongst the civilians in these installations, so, when they were attacked by the Syrian forces, the government could once again truthfully be accused of infringements of the Laws of Armed Conflict which themselves are underpinned by just war considerations. What we see here then is both parties to the asymmetrical war accusing one another of using terrorist methods. The allegations were true of both actors. In this kind of "tit for tat" activity the goal is/was to end up in the eyes of the international community as less ethically deplorable than the other party. This resulted in international political support (and thus power) flowing to the party whose ethical record was somewhat nearer the ethical high ground than the other party.

A central element of this kind of warfare involves what has come to be known as strategic communication. ${ }^{13}$ The fighting that is done is not what directly determines the success or failure of the project. The key element is

\footnotetext{
11 On ethical trapping see Lebow and Frost "Ethical traps" (2019).

12 Found in the Law on Armed Conflict (LOAC).

13 See the newly established journal Defence Strategic Communications (Riga, published by NATO).
} 
how "what has happened" or "what has been done" (and in particular the ethical dimensions of what has been done) is interpreted and how it is then communicated to both the local audience and the wider international one. What matters is which campaign of strategic communication triumphs in establishing one of the actors as more virtuous than the other. The regime of President Assad relied on a widely acknowledged principle of the international practice of sovereign states according to which a government of a sovereign state engaged in fighting terrorists seeking to destabilize the state, is, at the limit, when all else fails, entitled to use force against them. A basic principle in the practice of sovereign states is that a resort to violence by the citizens of a state with the aim of toppling a government is normally seen as not ethically justified. The only occasion when it would be considered justified is one where the existing government can rightfully be accused of ongoing gross and systematic human rights violations.

There is another dimension in which the belligerents traded ethical claims and counterclaims that are significantly different from those that we would have been produced by traditional just war theorists. The different parties in the ongoing war in Syria seek legitimacy not primarily by conquering and holding territory (as was the primary aim in conventional wars), Instead, the goal is to rule the people in a given territory and for the people being ruled to see the rule as legitimate. So, for example, the FSA sought to show itself legitimately ruling the population in eastern Aleppo. A primary function of any ruling authority is to provide peace and security for those over whom it rules. The regime, in order to deny the FSA s claim to be a legitimate ruler, was then set the task of proving by ongoing attacks on the civilians that the FSA was not able to provide peace and security. Indeed, what we saw then was that those over whom the FSA claimed to rule migrated in their hundreds of thousands either to refugee camps or to Western Aleppo which is/was ruled by President Assad's regime. By doing this, the FSA was left holding a territory but "ruling" an empty shell. The only way in which the FSA could have avoided this would have been by persuading the international community to intervene militarily by creating a no-fly zone thus blocking the barrel bombing helicopter attacks and thus protecting the civilian population.

\section{Radical Interpretation as an Approach to the Study of War}

What I have just provided is an interpretation of a brief tranche of action in the current war in Syria. As indicated earlier, I can do this, not because I am an expert in the details of Syrian politics, but because I am a participant in the 
relevant global practices in the same way that the readers of this chapter are. We are all insiders to this global practice within which we seek to reach decisions about rival interpretations of specified sets of action. As participants, we struggle to make sense of what has happened and what is happening in Syria. I want to stress that the kind of account I have just given (which can and ought to be elaborated in much greater detail) is not a narrow ethical evaluation that is parasitic on some prior empirical account of "the given." The account I have given is a primary level description of past and present activity in Syria and it is shot through with ethical components at every point. My account exhibits elements that must be present in any satisfactory account of social action, whether it be local or global. My claim is not that the short account I have given is the best one (I have no doubt there are other plausible accounts) but it is an example of the kind of ethically charged account that is required in the interpretation of this kind of activity. It is of course, easy to identify shortcomings in my interpretation. A better one would factor in the role of a slew of international actors that have been involved in the conflict from the outset, including, the USA and its allies, Turkey, Israel, Iran, and Russia. Yet, such an enriched account which highlighted the role of other international actors would itself have to factor in the ethical dimensions of their actions. It would refer to Russia's justifications according to which its military engagement was a response to a request from the legitimate Syrian government which was facing ethically unjustifiable attacks from a range of terrorist groups. It would refer to Turkey's claims to be facing down Kurdish rebels who were using the war in Syria to establish a launching pad for an ethically unjustified war of liberation against Turkey. In describing the role of each of these actors, at every point my account would necessarily involve me making ethical judgements about their actions. Taken in the round, I have called this approach radical interpretivism.

Here once again are the key characteristics of this method? They are: first, that the actors whose actions are being investigated have to be understood as participants in the relevant global practices; second, that the actions they perform can only be understood within these practices understood from the internal point of view; third, the practice has to be understood as a whole; fourth, that understanding the actors and their actions in these practices requires of the investigator an understanding of the ethical components of the relevant practices. An implication of the above is that the investigator necessarily becomes in some broad sense a participant in the practice being investigated.

In international relations at present the relevant practices that have to be investigated in order to understand the constitution of the participants and the actions that are available to them are: the society of sovereign states, on the 
one hand, and the global rights practice (sometimes referred to as global civil society) on the other. ${ }^{14}$

As already indicated, the society of sovereign states is a global practice within which states constitute one another as actors (as participants) of a certain kind. The practice is not properly understood as an association formed by previously existing states going through some contractual procedure to form an association. It is only within this practice that states properly so-called come into being. ${ }^{15}$ In constituting one another as sovereign states the participants in this practice constitute themselves as having certain freedoms in a field of diverse states.

The global rights practice is one in which individual men and women constitute one another as the holders of fundamental human rights, that is, they constitute themselves as having equal sets of freedoms (rights) in a field of diverse human actors. In it there are ongoing arguments about what rights constitute the final list, but there is agreement on the core of central rights including the well-known list of negative liberties. The ethical value contained in the global rights practice is the freedom the participants create for one another through recognising each participant as a rights holder. What rights-holders value, in this global practice is the freedom they accord one another to pursue widely different plans of the good life.

Most people are simultaneously participants in both global practices, that is, they are citizens in the global practice of sovereign states and they are rights holders in the global rights practice. Both practices are macro practices in the sense that they contain within them multiple other practices. They are practices of practices. So, for example, within the practice of sovereign states, we find families, churches, clubs, universities, trades unions, and many other social formations. Similarly, the rights holders in the global rights practice, itself a practice of practices, create for themselves many different practices (political, religious, cultural and sporting, to mention but a few).

Some points to highlight here are that anyone seeking to understand (explain or describe) the actions of states can only do that once they have a grasp of the fundamental constitutive rules of the practice (metaphorically speaking they need knowledge of the "rules of the game" that constitute the practice); that the practices are not static, but change as the participants in

14 In previous historical periods, there existed different kinds of global practices (feudal; imperial; tribal; amongst others.

15 Any entity that calls itself a state, but which is not given the appropriate recognition by the society of sovereign states is not a state. A good example of this is the Republic of Somalia which is located within the state of Somalia. 
them confront novel circumstances which lead them to modify their practices; and that, bringing about change requires of them that they interpret the novel circumstances in the light of the existing "rules of the game" and are informed by the underlying ethical considerations embodied in the practice. The space of creative interpretation in these practices is similar to that which takes place in legal systems where judges are called upon to interpret the law to cover novel circumstances. The process involved in the law has been graphically portrayed by the late Ronald Dworkin. ${ }^{16}$ The key point in all of this, is that providing an interpretation of a single action or a series of actions over time (a history), whether these be carried out by individual actors, collective actors such as a state or a corporation, or a group of collective actors, such as an alliance of states or alliance of companies, involves taking into account the ethics embedded in the practices within which they are constituted as actors able to carry out such actions.

To demonstrate these features of practical life, briefly I return to the account of the Syrian war I set out above. To make sense of the actions of the FSA, I had to draw attention to the way in which the organisation sought to secure international support for its struggle. This involved drawing attention to the atrocities being performed on them by the government of Pres Assad's and his military forces. The notion of "atrocity" can only be understood in terms of the ethical values embedded in both global practices. In these it is considered wrong for state governments to barrel bomb their own citizens for by so doing they show a basic disregard for the fundamental human rights of their own citizens. In like manner, in order to understand the bombing carried out by Pres Assad's forces, I had to draw on our knowledge, as participants in the global practices, of the ethical duty incumbent on the governments of sovereign states to protect their citizens from terrorist attacks from whatever quarter they may come. Of course, there is an argument to be had about the status of the FSA. Is it to be understood as in some broad sense a liberation movement that has had to resort to violence (as a last resort) in the face of systematic persecution of its people by the government, or, is it to be understood as an illegitimate terrorist organisation, seeking to overthrow a legitimate government. This argument, like the others I mentioned above, is an ethical one. Reaching a justifiable conclusion about this matter would require a complex ethical enquiry into the recent history of the Syrian state, the role it has played in the relations among states in the region, and its role more widely in the global society of sovereign states.

16 See his Taking Rights Seriously. 
I think I have said enough to buttress my main argument in this chapter which is that in order to understand the complexities of asymmetrical warfare, the dominant form of warfare in the world today, the traditional just war tradition is of limited use. Instead, what is called for is what I have termed critical interpretivism. This involves interpreting the actions of the participants in such wars not in some micro context, but, in the context of the global practices within which the actors conduct their hostilities. These are the society of sovereign states and the global rights practice. It is of fundamental importance that all actors in contemporary international relations are understood to be participants simultaneously in both of these practices - in the first as a citizen of a sovereign state and in the second as a rights holder in the global rights practice. Social scientists seeking to do this, must engage in an interpretive exercise of the actors and their actions as they participate within both practices when they engage in such wars. Descriptions of what is being done and what has been done require the making of fine ethical judgements.

\section{Bibliography}

Fisher, D., The Morality of War. Oxford: Oxford University Press, 2011.

Kaldor, M., New and Old Wars: Organized Violence in a Global Era. Cambridge: Polity Press, 1998.

Lebow, R. N., and Frost., M., "Ethical Traps in International Relations." International Relations 33, no. 1 (2019): $3^{-22 .}$

Walzer, M., Just and Unjust Wars: A Moral Argument with Historical Illustrations. Harmondsworth: Penguin, 1980. 